so much so that the mother collapsed. I turned as quickly as possible after administering stimulants, but the difficulty did not end here, as the chin became locked in that of the fifth. There were some difficulty and considerable delay in freeing them, though the extent of the locking was not at any time formidable. The child was dead (recently). The fifth was a hesd presentation and the child was delivered naturally ; it was alive and lived for half an hour. The placenta was delivered about five minutes after the birth of the last child and consisted of two portions united by a narrow isthmus. One, the smaller, had two cords attached centrally and close together; the other, and larger, had two cords attached in a similar way to the former, and one where it was joined by the isthmus. It appeared to be perfectly healthy. The cord of the fourth child was so short that it had to be tied in the vagina. The mother rallied quickly and has gone on well. The children were all females and much about the same size, making a total weight of eight pounds, or, on an average, a little over one pound and a half each.

Rainham, Essex.

\section{A PECULIAR CASE OF DISLOCATION OF THE SHOCLDER-JOINT.}

Br C. C. BaXter-Tyrie, M.B., C.M. EdIN,

The methods by which a joint may become dislocated are cany and various. Especially is this true as regards the shoulder-joint, andixthe following case, being perhaps unique, seems worthy of being added to the list of peculiar histories of causation. On Sept. 18th I was called to see a patient whom I found suffering from a subcoracoid dislocation of the head of the humerus. On inquiring as to the cause of the injury I elicited the following peculiar history. The man was returning on horseback from the smithy to his house when the horse ran away up a steep hill. The animal after going a few hundred yards abated speed, and the rider, with the intention of "taking it out of the brute," raised his hand to strike. The horse canght sight of the whip and sprang forward, with the result that the man felt an acute pain and a sense of something having given way in his shoulder. He did not fall off, but rode a little further into a farmyard, where he was helped to dismount. Had he been thrown I should have been dubious as to the above history of causation. As the weight of the whip was inconsiderable (four ounces) the explanation of the cause of injury is, I think, found in the inertia of the arm converting it into a dever of the first order. The coraco-acromial arch, instead of fulfilling its normal function of preventing displacement, acted in this case as a fulcrum. The limb from the fingers to that point acted as the "long arm," and the head and part of the neck of the humerus served as the "short arm." "The inertia of the arm, left as it were behind, supplied the power, while the ruptured capsular ligament and displacement of the head of the bone would represent the work done.

Victoria-road, Keighley.

NOTES AND OBSERVATIONS ON A CASE OF SUPPOSED DELAYED INHERITED SYPHILIS.

By Tom Robinson, M.D. St. ANd.

A MAN aged thirty-six consulted me in January, 1890, for a swollen testicle, which he said had crept slowly and painlessiy on. There was an absence of any history of 3onorrhœa, injury, or previous attack. On examination the left testicle was found to be as large as a sheep's beart. The epididymis was not involved. The surface of the testicle was smooth and was somewhat pearshaped. It had that dense, heavy feel which has always been noticed in cases of syphilitic orchitis. A most careful inquiry was made into the history of the case, without discovering any subjective or objective evidence of syphilis, the narrative being free even from evidence of the Dossibility of contagion. The patient was a married man and the father of four children, all of whom were apparently bealthy. His wife was free from any display of syphilis, and she had never miscarried It was not possible to carry the history of the patient any further back, as his parents bad been dead for some years and he was an only child.
His childhood had been, so far as he knew, a healthy one, and he certainly betrayed no evidence, so far as physiognomy or teeth were concerned, of having inherited a syphilitic taint. Sir James Paget was good enough to see the case with me, and he corroborated the opinion that it was one of delayed inherited syphilis. The patient was ordered to rub a drachm of blue ointment into the enlarged gland twice a day, and, at the same time, to take a mixture three times a day containing five grains of iodide of potassium in each dose. In six weeks the volume of the testicle had diminished until there was little apparent difference between the two organs.

Experience has already demonstrated the fact that inherited syphilis has three epochs of activity: $(a)$ where it manifests itself at or about birth; $(b)$ where it manifests itself during childhood; and $(c)$ where the disease is delayed until after puberty. Cases such as this one are, I believe, not uncommon. If inherited syphilis will lie dormant for six years, why should not the period be prolonged to thirty-six? We know that in the acquired form of the malady there is no limit to the time in which the organism may not be attacked by the sequelæ. The sequelæ of scarlet fever, measles, and other blood diseases will spread over a number of years, and senile scrofula has become current coin in the medical profession. The interest of all syphilitic problems lies in the attemnt to follow backwards the footmarks of the poison. Our difficulties are sometimes insurmountable, but there is no disease which leares in its path so many evidences of its march and none which possesses a more potent interest.

Prince's-street, W.

\section{A attitror}

\section{H O S I T A L P R A C T C E, BRITISH AND FOREIGN.}

Nulla autem est alia pro certo noscendi via, nisi quamplurimas et morborum et dissectionum historias, tum aliorum tum proprias collectas habere, et inter se comparare.-MoRGAGNI De Sed. et Caus. Morb., lib. iv. Procemium.

\section{ST. THOMAS'S HOSPITAL.}

A CASE OF TUBERCIE OF THE BLADDER IN A MALE; SUPRAPUBIC CYSTOTOMY ; RECOVERY.

(Under the care of Mr. W. H. BATrte.)

WE have published this year in THE LANCET other cases of supra-pubic cystotomy for the cure of tubercle of the bladder in the male, and in most of them the results were very satisfactory. It is admitted that in this case a sufficiently long period of time has not elapsed since the patient left the hospital to enable it to be said with certainty that the man is cured, but the prospect is undoubtedly good, and the benefit already received is great. Tuberculous disease of the bladder is one of the most painful of all affections of that viscus, the frequent painful micturition being most distressing, and the patient obtaining but little rest, either day or night, whether in bed or going about. It is not surprising, therefore, that there is now a tendency to attack the disease boldly and directly when examination of the patient makes it probable that the disease is primarily of the bladder and has not extended to other parts. The results already obtained are so satisfactory as recorded that no surgeon can be blamed for refusing to continue week after week medication through the urethra with an uncertain result in cases such as that described, when an incision above the pubes will enable him to exactly gauge the extent of the mischief and arrest its progress by scraping, the bladder being subsequently drained for a few weeks. For the notes of the case we are indebted to Mr. Paterson, dresser.

A tall, strongly built man aged thirty-one was admitted to St. Thomas's Hospital, under the care of Mr. Mackellar, on July 20th, 1895. The family history was good; there was no history of phthisis. He was a married man with two healthy children. There was no illness of moment in the previous history. The first symptom noticed was severe pain in the penis fire months before admission, followed by a 